Contents list avaliable at Directory of Open Access Journals (DOAJ)
$\begin{gathered}\text { Aulad : Journal on Early Childhood } \\ \text { Vol 4 No 2 2021, Pages 128-135 } \\ \text { ISSN : 2655-4798 (Printed); 2655-433X (Online) } \\ \text { Journal Homepage: https://aulad.org/index.php/aulad }\end{gathered}$

\title{
Manajemen Pembelajaran Anak Usia Dini Berbasis Inovasi Unggulan di MasaPandemi Covid-19
}

\author{
Marjanis $^{1 凶}$, Rifma $^{1}$, Syahril $^{1}$ \\ Universitas Negeri Padang, Padang, Indonesia (1) \\ DOI: 10.31004/aulad.v4i2.124 \\ Corresponding author: \\ [marjanismarjanis@gmail.com]
}

\begin{abstract}
Article Info
Abstrak

Kata kunci:

Manajemen

pembelajaran;

Pandemi covid 19;

Program inovasi

unggulan;

Pembelajaran anak usia dini di masa pandemi memerlukan perhatian khusus, karena anak usia dini memerlukan bimbingan yang khusus berbeda dengan anak usia sekolah lainnya. Penelitian ini bertujuan untuk mendeskripsikan manajemen pembelajaran berbasis program inovasi unggulan pada masa COVID-19 di TK Pembina Pasa-Balai Parit Malintang Padang Pariaman. Pendekatan yang digunakan, deskriptif kualitatif dengan teknik pengumpulan data yaitu observasi, wawancara dan dokumentasi. Analisis data menggunakan teknik Miles dan Huberman yaitu reduksi, display data dan kesimpulan. Hasil penelitian menunjukan, manajemen pembelajaran anak usia dini berbasis program inovasi unggulan di masa pandemi COVID-19 yaitu perencanaan, pelaksanaan pembelajaran dengan inovasi unggulan dan evaluasi. Perencanaan berisi program inovasi unggulan, narasi pembelajaran, pembagian bahan ajar dan pembuatan video edukatif. Pada pelaksanaan, guru mengaplikasikan program inovasi unggulan seperti program panggung edukasi yang direkam dengan apikasi rekam layar, platform digital learning, program Bahasa Inggris dan Bahasa Minang. Pada evaluasi pembelajaran guru memberikan penilaian dan melaksanakan kegiatan discution and trainer.
\end{abstract}

\section{Keywords:}

Learning management;

COVID-19 pandemic;

Excellent innovation

program;

\begin{abstract}
Early childhood learning during the pandemic requires special attention, because early childhood requires special guidance that is different. This study aims to describe learning management based on superior innovation programs during the COVID-19 period at the Pembina Pasa-Balai Parit Malintang, Padang Pariaman. The approach used is descriptive qualitative with data collection techniques, namely observation, interviews and documentation. Data analysis used the Miles and Huberman technique, namely reduction, data display and conclusions. The results showed that early childhood learning management was based on superior innovation programs during the COVID-19 pandemic, namely planning, implementing learning with superior innovations and evaluation. The plan contains superior innovation programs, learning narratives, distribution of teaching materials and making educational videos. In implementation, teachers apply superior innovation programs such as educational stage programs recorded with screen recording applications, digital learning platforms, English and Minang language programs. In the evaluation of learning the teacher provides an assessment and carries out discussion and trainer activities.
\end{abstract}




\section{PENDAHULUAN}

Pandemi virus corona atau yang dikenal dengan coronavirus disease 2019 (COVID-19) telah mengubah berbagai tantangan kehidupan manusia sejak dua tahun terakhir. Dunia pendidikan pun tidak dapat mengelakkan dampak dari virus ini karena sistem pendidikan harus mengalami perubahan untuk menyesuaikan pelaksanaan pembelajaran di masa pandemi. Banyak sekolah yang belum siap dalam pembelajaran jarak jauh (PJJ), sehingga menyebabkan proses pembelajaran tidak efektif. Pendidik, orangtua dan peserta didik masih belum terbiasa melaksanakan proses pembelajaran jarak jauh dikarenakan belum beradaptasi dengan kebiasaan dan situasi pandemi COVID-19. Pembelajaran jarak jauh memiliki berbagai konsekuensi yang harus dijalani oleh guru, peserta didik dan orang tua, terutama dalam mengatasi permasalahan jaringan internet. Namun, pada dasarnya, lembaga pendidikan juga harus berperan aktif dalam mendukung terwujudnya pembelajaran yang inovatif dalam masa pandemi ini, agar seluruh pihak yang terkait seiring sejalan dalam menerapkan pembelajaran yang berkualitas. Tujuannya agar peserta didik nyaman dalam mengikuti pembelajaran, meskipun berhadapan dengan covid19. (Karim, 2021; Wahyuni, 2021).

Pandemi COVID-19 sebagai tantangan dalam menjalankan kehidupan yang memiliki dampak yang cukup besar dalam keberlangsungan pendidikan. Menurut penelitiansebelumnya oleh (Syah, 2020) bahwa terdapat dua dampak pandemi COVID-19 yang dirasakan diantaranya dampak jangka pendek dan dampak jangka panjang. Di Indonesia dampak pandemi COVID-19 dirasakan oleh banyak keluarga baik desa atau di kota. Dalam pendidikan, banyak keluarga yang kurang familiar melakukan sekolah di rumah. Demikian juga dengan problem psikologis anakanak peserta didik yang terbiasa belajar bertatap muka langsung dengan guru-guru mereka. Pelaksanaan pembelajaran berlangsung dengan cara pembelajaran jarak jauh/online. Penduduk di desa terpencil pada usiasekolah serba kebingungan sebab infrastruktur informasi teknologi sangat terbatas. Penilaian siswa bergerak online dan banyak trial and error dengan sistem yang tidak ada kepastian. Dampakjangka panjang COVID-19 yaitu aspek keadilan dan peningkatan ketidaksetaraan antar kelompokmasyarakat dan antar daerah (Karim, 2021).

Sebagai panduan dalam pelaksanaan pembelajaran jarak jauh atau dikenal juga dengan belajar dari rumah, Kementerian Pendidikan dan Kebudayaan dalam surat edaran Nomor 15 tahun 2020 tentang pedoman penyelenggaraan belajar dari rumah dalam masa darurat penyebaran Corona Virus Disesase (Kemendikbud, 2020). Mendukung kebijakan pemerintah tersebut, Pemerintah Kabupaten Padang Pariaman juga telah memberlakukan pelaksanaan pembelajaran dari rumah selama masa pandemi.

Penelitian tentang kualitas pembelajaran untuk anak usia dini diantaranya telah dilaksanakan oleh (Hanifah, 2018) yang mengemukakan bahwa dalam meningkatkan kualitas pembelajaran di POS PAUD Dahlia 15, manajemen pembelajaran diantaranya perencanaan, pelaksanaan, dan evaluasi. Perencanaan pembelajaran mengacu pada kurikulum nasional dan menyiapkan RPPH. Pelaksanaan pembelajaran menggunakan metodedan media yang kreatif sedangkan evaluasi pembelajaran menggunakan portofolio, anekdot dan pengamatan. Penelitian yang lain oleh (Hadiati \& Fidrayani, 2019) bahwa manajemen pembelajaran pendidikan anak usia dini yang dilakukan se RA Kota Bandar Lampung dimana kegiatan pelaksanaan pembelajaran di sebagian besar RA se Kota Bandar lampung dalam merealisasikan perencanaan pembelajaran dimulai menyusun program tahunan, program semester, RKM dan RKH. Pelaksanaan pembelajaran disesuaikan dengan RKH/RPPH.Sedangkan pengawasan dilakukan oleh penilik atau pengawas. Penilaian dilakukan setiap hari, perbulan dan pertahun. Penelitian yang sama tentang manajemen pembelajaran oleh (Azwardi, 2015) bahwa manajemen di PAUD Cempaka SKB Musi Rawas

diantaranya perencanaan,pengorganisasian, pelaksanaan dan monitoring. Pengorganisasian dilakukan oleh pengelola dan para tutor. Pelaksanaan pembelajaran dilakukan sesuai perencanaan pembelajaran dan monitoring/evaluasi dilaksanakan oleh pengawasdan penilik.

Pada penelitian terdahulu tersebut diketahui tentang pentingnya manajemen pembelajaran anak usia dini yang meliputi perencanaan, pelaksanaan pembelajaran, evaluasi dan pengawasan. Perbedaan penelitian ini dengan tiga penelitian terdahulu adalah dalam hal pembelajaran jarak jauh, inovasi yang diterapkan antara lain berhubungan dengan digital learning yang mendukung untuk pembelajaran di masa pandemi. Aktivitas manajemen dapat berupapengelolaan, kepemimpinan, atau pengarahan (Suyadi, 2011). Selain itu aktivitas manajemen dapat berupa perencanaan, pengorganisasian, pengarahan dan pengawasan usaha para anggota dan penggunaan sumber daya dan sumberdaya organisasi lainnya agar mencapai tujuan organisasi yang telah ditetapkan bersama Utiarahman et al., 2020). Pembelajaran membutuhkan proses interaksi pesertadidik dengan pendidik dalam suatu lingkungan belajar, maka manajemen pembelajaran sebagai upaya untuk mengendalikan dan mengatur aktivitas pembelajaran berdasarkan konsep dan prinsip pembelajaran guna mengsukseskan tujuan pembelajaran agar tercapai secara lebih efektif, efisien dan produktif.(Karim, 2021).

Pada TK Pembina Pasa-Balai selama pandemi COVID-19 manajemen pembelajaran terus ditingkatkan baik dalamperencanaan, pelaksanaan dan evaluasi pembelajaran. Program kegiatan terus ditingkatkan dan diciptakan sehingga melahirkankegiatan yang berbeda dan menarik untuk anak dalam memberikan pelayanan yang optimal. Senada dengan penelitian Fitri (2020) bahwapengelolaan program pendidikan anak usia dini sebagai proses tahapan untuk mengatur program dan pengelolaan lembaga dalam upayameningkatkan pelayanan kemajuan sekolah. 
Program inovasi unggulan di TK Pembina Pasa-Balai diantaranya program panggung edukasi dengan menggunakan bonekatangan, platform digital learning yaitu whatsapp video call dan program bahasa yaitu bahasa jawa dan inggris. Ketiga program tersebut merupakan inovasi pembelajaran di TK Pembina Pasa-Balai.Oleh karena itu, peneliti tertarik ingin membedahlebih dalam terkait bagaimana manajemen pembelajaran anak usia dini berbasis program inovasi unggulan dimasa pandemi COVID-19 diTK Pembina Pasa-Balai. Berdasarkan masalah tersebut maka tujuan penelitian ini adalah mengetahui manajemen pembelajarananak usia dini berbasis program inovasi unggulandi TK Pembina Pasa-Balai pada masapandemi COVID-19.

\section{METODE PENELITIAN}

Pendekatan penelitian ini adalah deskriptifkualitatif. Deskripsi yang ingin dihasilkan dari penelitian ini adalah tentang manajemen pembelajaran anak usia dini pada masa pandemi COVID-19. Penelitian ini bertempat di Taman Kanak-Kanak Pembina Pasa-Balai Padang Pariaman selama2 bulan yaitu bulan Mei sampai Juni tahun 2021.

Teknik pengumpulan data yang digunakan dalam penelitian ini yaitu observasi, wawancara terstruktur, dokumentasi dan triangulasi. Dalam observasi, peneliti melakukan pengumpulan data menyatakan terus terang kepada sumber data bahwa ia sedang melakukan penelitian. Dalam wawancara terstruktur, peneliti telah mengetahu informasi yang akan diperoleh sehingga telah menyiapkan instrument penelitian berupa pertanyaanpertanyaan tertulis. Dua sumber penelitian yangdigunakan yaitu sumber data primer dan sekunder. Sumber data primer yaitu kepala sekolah dan guru kelas sedangkan sumber data sekunder yang digunakan yaitu buku, jurnal dan dokumentasi.

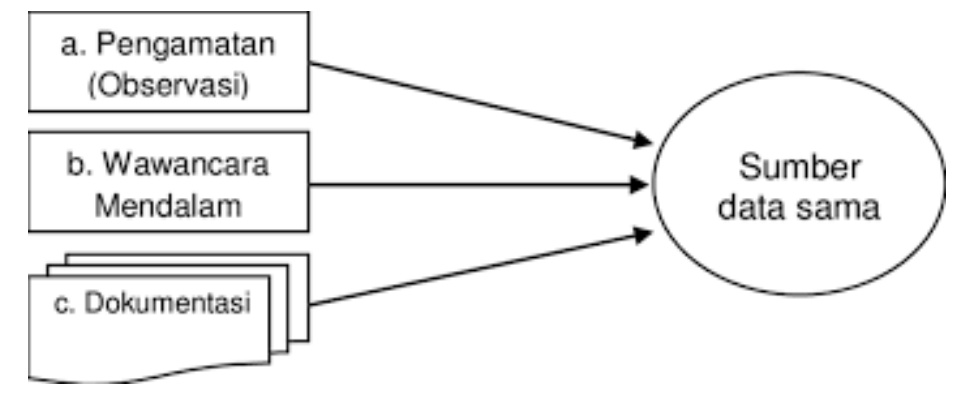

\section{Gambar 1. Triangulasi Teknik Pengumpulan Data}

Teknis analisis data menggunakan teknik Miles dan Huberman dimana aktivitas dalam analisi data dilakukan secara interaktif danberlangsung secara terus menerus sampai tuntas sehingga datanya sudah jenuh. Aktivitas dalam analisis data yaitu data reduction, data display dan conclusion drawing.

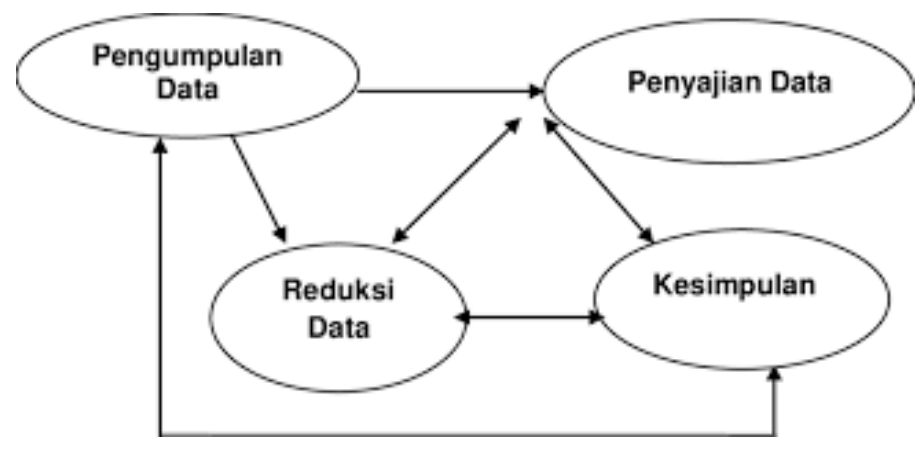

Gambar 2. Teknik Analisis Data Miles dan Huberman

\section{RESULT AND DISCUSSION}

Program inovasi unggulan pada masa pandemi COVID-19 di TK Pembina Pasa-Balai terbagi menjadi tiga bagian yaitu (1) perencanaan pembelajaran meliputi penyusunan kurikulum, program semester, RPPM, narasi pembelajaran, bahan ajar dan pembuatan video program inovasi unggulan; (2) pelaksanaan meliputi pengaplikasian program platform digital learning dan program bahasa, (3) evaluasi meliputi penilaianpembelajaran dan discution and traninner (D\&T). 


\section{Perencanaan pembelajaran jarak jauh di TK Pembina Pasa-Balai}

Rencana pelaksanaan pembelajaran (RPP) merupakan pedoman bagi guru dalam melaksanakan pembelajaran. RPP yang disusun harus relevan dengan Kompetensi Inti (KI) dan Kompetensi Dasar (KD) keberhasilan pengelolaan pembelajaran yang bermakna, membangun sikap, keterampilan, pengetahuan, dan mengarahkan guru dalam menyiapkan alat dan bahan yangdiperlukan. Perencanaan pembelajaran program inovasi unggulan jarak jauh selama pandemi COVID-19 di TK Pembina Pasa-Balai diantaranya guru dan kepala sekolah membuat kurikulum, prosem, membuat rencana pelaksanaan pembelajaran mingguan, mempersiapkan narasi pembelajaran dan pembuatan video edukatif. Penyusunan RPP tersebut harus memperhatikan karakteristik peserta didik yang akan mengikuti pembelajaran (Karim, 2021).

Beberapa kegiatan yang dilaksanakan untuk melaksanakan PJJ di TK Pembina Pasa-Balai pada masa pandemi COVID-19 yakni diawali dengan membuatkurikulum. Penyusunan kurikulum di TK Pembina Pasa-Balai dilaksanakan sebelum masuk pembelajaran setiap semester dan membentuktim pengembang kurikulum untuk mempermudah dalam proses pembuatan kurikulum. Tim pengembang kurikulum terdiri dari ketua, sekretaris, bendahara, komite, anggotadan narasumber yang diputuskan oleh kepala sekolah. Kurikulum di TK Pembina PasaBalai mengacu pada Permendikbud 146tahun 2014 dan Permendikbud 137 tahun 2014. Perencanaan kurikulum memperhatikan beberapa aspek seperti perkembangan nilai agama dan moral, fisik motorik, bahasa, kognitif subtema dan atau sub-sub tema; (e) menentukan alokasi waktu untuk setiap tema. Pada TK Pembina Pasa-Balai program semester tahun ajaran 2020/2021 terdiridari enam tema dan subtema diantaranya tema diriku subtema identitas diri, tubuhku, benderakudan lagu kebangsaan dengan alokasi dua minggu.Tema negaraku sub tema lambang negara, dasar negara, benderaku, lagu kebangsaan dengan alokasi waktu tiga minggu. Tema lingkunganku subtema rumahku, sekolahku, tokoh disekitar, tempat-tempat umum dengan alokasi waktu empat minggu. Tema kebutuhanku subtemamakanan, minuman, pakaian, kesehatan, bermaindengan alokasi waktu empat minggu. Tema binatang subtema binatang buas, jinak, serangga dan purba dengan alokasi waktu empat minggu. Tema tanaman subtema tanaman hias, buah, sayur dan obat dengan alokasi waktu tigaminggu. Semua tema akan masuk kedalam program inovasi unggulan dalam kegiatan yang akan dilaksanakan oleh anak.

Kompetensi Dasar yang harus dicapai dalam satu semester antara lain agama dan moral, fisik motorik, kognitif, sosial emosional, bahasa dan seni. Kurikulum sebagai perangkat untuk merencanakan dan mengatur tentang tujuan, isi dan bahan pelajaranserta cara yang digunakan sebagai pedoman penyelenggaraan kegiatan pembelajaran untuk mencapai tujuan pendidikan tertentu (Nurmiati, 2018). Program inovasi unggulan di TK Pembina Pasa-Balai telah diatur dalam kurikulum sekolah sebagai kegiatan unggulan yang dijabarkan dalam program tahunan. Rencana PJJ yang kedua yaitu membuat program semester. Program semester berisi kompetensi dasar, daftar tema satu semester yang dikembangkan menjadi subtema dan dapat dikembangkan menjadi subsubtema serta alokasi waktu setiap tema. Adapun langkah- langkah dalam penyusunan program semester di TK Pembina Pasa-Balai: (a) menetapkan kompetensi dasar di setiap tema yang memuat aspek perkembangan nilai agama dan moral, fisik motorik, kognitif, bahasa, sosialemosional dan seni; (b) kompetensi dasar ditulis lengkap atau kodenya saja ditetapkan dalam setiap tema; (c) membuat daftar tema satu semester; (d) mengembangkan tema menjadi Rencana pembelajaran yang ketiga selama COVID 19 yaitu membuat RPPM. Rencana Pelaksanaan Pembelajaran Mingguan (RPPM) disusun untuk satu minggu (Fadlillah, 2018; Pamungkas, Hayati, \& Maryatun, 2016). Rencana mingguan di TK Pembina Pasa-Balai dijabarkan dari program satu semester yang berisi identitas program layanan, KD, materi dan rencana kegiatan. Identitas program layanan memuat nama satuan PAUD, kelompok usia, semester atau bulan atau minggukeberapa, tema, sub tema dan sub sub tema.

Kompetensi dasar seperti kelompok satu sikap spiritual, kelompok dua sikap sosial, kelompok tiga pengetahuan dan kelompok empatketerampilan di TK Pembina Pasa-Balai termuat dalam RPPM yang ditetapkan dari program semester. Materi pembelajaran diambil mengenal lagu bahasa minang, bercerita denganboneka tangan dan yang lainnya. Selama pembelajaran jarak jauh rencana pembelajaran yang disiapkan yaitu membuat narasi. Narasi pembelajaran di TK Pembina Pasa-Balai memuat kata-kata dari guruyang berisi kompetensi dasar, kompetensi inti, materi pembelajaran, tema kegiatan, subtema kegiatan, asfek perkembangan anak dan pesan kepada orangtua. Narasi pembelajaran disampaikan sebelum kegiatan dimulai yaitu hariSenin pagi untuk satu minggu kegiatan.

Adapun teks narasi pembelajaran di TK Pembina Pasa-Balai sebagai berikut; "Ayah / Bunda". Tema bermain minggu ini adalah "Kendaraan, Kendaraan Darat".

Tujuannya agar tercapainya enam aspek perkembangan dalam kegiatan yaitu: (1) menghafal doa pendek, (2) melakukan kegiatan motorik kasar dan halus, (3) mengenal bentuk, nama, warna kendaraan, (4) sikap pedulidan mau membantu, (5) aktivitas seni musik dan kriya. Kegiatannya yaitu: (a) aku membaca do'a sebelum bepergian; (b) asyiknya menggambar mobil; (c) ayo membuat mobil-mobilan dari botolaqua bekas bersama ayah bunda; (d) Serunya membersihkan kendaraan bersama ayah; (e) video call edukasi tema kendaraan. Para orang tua diperbolehkan memilih tema yang dianggap paling menarik. Orang tua diharapkan membantu dalam memotivasi anak dalam belajar, dan diupayakan agar tema yang dipilih lebih dekat dengan lingkungan anak, atau peralatan permainan yang sering digunakan anak dalam keseharian. Orang tua diminta untuk mau bekerjasama dalam merekam dan mendokumentasikan seluruh kegiatan yang dilakukan dalam tema yang dipilih tersebut untuk dilaporkan ke grup 
Whatsapp, yang selanjutnya akan dicatat oleh guru ke dalam perkembangan pembelajaran anak. Untuk kegiatan ibadah, orang tua diminta untuk mengisi google form yang linknya sudah disediakan di grup.

Ketika menyampaikan narasi pembelajaran di TK Pembina Pasa-Balai terdapat standar operasional prosedur yang tujuannya agar orangtua dapat memahami kegiatan daring yang akan dilaksanakan anak danuntuk memperjelas kegiatan bermain yang akan dilakukan oleh anak selama pembelajaran daring.Adapun prosedur narasi pembelajaran di TK Pembina Pasa-Balai yaitu: (a) guru memiliki rencana dalam satu minggu; (b) guru memiliki narasi teks yang akan disampaikan kepada orangtua; (c) guru mengatur jadwal bersama orangtua; (d) guru menyampaikan narasimelalui pesan video; (e) guru mendampingi anakdalam BDR melalui daring selama 2,5 jam dalamsatu hari; (f) guru meminta hasil belajar kepada orangtua melalui foto atau video; (g) Guru menilai karya anak.

Perencanaan PJJ di masa COVID-19 sekolah mempersiapkan bahan ajar. Persiapan bahan ajar di TK Pembina Pasa-Balai dilakukan setiap minggu, dimana bahan-bahan yang disiapkan disesuaikan dengan kegiatan rencana pelaksanaan pembelajaran mingguan. Bahan-bahan yang dipersiapkan harus berupa bahan yang relevan dengan tema yang dipelajari oleh peserta didik, misalnya boneka tangan, alat tulis, panggung edukasi, bahan sesuai tema, , cat air, kertas warna, kertas karton, dan yang lainnya. Selain itu, guru juga mempersiapkan video edukatif yang dapat direkam menggunakan aplikasi rekam layar dengan durasi maksimum 15 menit yang akan dibagian ke grup WhatsApp dimana setiap akhir pekan, guru merekam materi seperti materi kosakata bahasa Indonesia yang diselingi dengan Bahasa Minang dan Bahasa Inggris. Media video pembelajaranmenyajikan audio visual yang berisi pesan pesanpembelajaran (Gusliati et al., 2019).

\section{Pelaksanaan Pembelajaran Jarak Jauh Berbasis Program Inovasi Unggulan di TK Pembina Pasa-Balai}

Pelaksanaan PJJ di TK Pembina Pasa-Balai dilakukan selama lima hari dalam seminggu, yang mana jadwalnya disepakati dengan orang tua peserta didik, namun tentunya tetap memperhatikan jam kerja guru. Program pembelajaran inovatif dengan bantuan teknologi dirancang oleh guru dengan bimbingan Kepala Sekolah sehingga program-program pembelajaran yang dilaksanakan tetap menarik bagi peserta didik. Dengan demikian, peserta didik tetap dapat belajar, komunikasi orang tua dengan guru terjalin dengan baik untuk terwujudnya pembelajaran berkualitas. Beberapa program yang dilaksanakan antara lain tentang panggung edukasi yakni dengan menampilkan video guru bercerita menggunakan boneka tangan, menggunakan video call dengan WhatsApp dan menggunakan bahasa Indonesia, Minang dan Inggris.

Untuk kegiatan panggung edukasi, guru melakukan perekaman video menggunakan aplikasi rekam layar, dimana panggung edukasi di desain semenarik mungkin dan dilengkapi dengan boneka tangan untuk mendukung alur cerita. Setelah itu video dikirim ke grup WhatsApp minimal satu hari sebelum pembelajaran dilaksanakan dan orang tua diminta untuk mendampingi anak menonton video tersebut. Kemudian, pada saat pembelajaran dilakukan secara singkron melalui video call WhatsApp, yang mana saat ini aplikasi video call sudah bisa dilakukan hingga 8 orang. Guru mengulang sejenak tentang cerita yang sudah disajikan lewat video panggung edukasi yang sudah dikirim ke grup, dan kemudian meminta peserta didik meniru beberapa bagian yang diingat oleh peserta didik dengan cara masing-masing. Setiap anak diberi waktu 2 menit untuk praktik, dan hal ini bertujuan untuk mendidik anak untuk lebih aktif dan kreatif.

Setelah anak selesai menyajikan jalan cerita di poin-poin yang mereka ingat, guru mengulas lebih kurang satu menit saja tentang hikmah dan pelajaran yang dapat ditarik dari alur cerita. Guru disarankan untuk tetap memberikan pujian dan motivasi kepada anak yang berani maju menyajikan potongan cerita tersebut. Untuk menanamkan sikap bertaqwa kepada Allah, dan membiasakan tertib, peserta didik dibiasakan untuk berdoa di awal dan penutup pembelajaran, dimana doa dapat dipimpin oleh guru ataupun oleh peserta didik yang sudah mulai bisa berdoa. Pengambilan presensi atau kehadiran peserta didik dilakukan dengan momen foto bersama menggunakan screenshoot, dan agar anak merasa lebih semangat, mereka dipersilahkan mengambil pose menarik ketika dilakukan pengambilan foto absen.

Metode dalam kegiatan panggung edukasiini yaitu cerita dimana guru menceritakan materisesuai tema seperti kepedulian terhadap sesama dengan media boneka tangan, tanya jawab dimana guru memberikan pertanyaan kepada anak tentang bagaimana sikap peserta didik apabila ada kerabat atau teman yang sakit. Guru memberikan nasehat agar anak terbiasa peduli dengan lingkungan sekitar, terutama kerabat dan teman sepermainan. Metode adalah cara yang digunakan untuk melaksanakan perencanaan atau strategi agar tujuan yang telah disusun mencapai maksimal (Sriwahyuni et al., 2017); Karim, 2021)

Kegiatan program inovasi unggulan keduayaitu platform digital edukasi menggunakan videocall WhatsApp. Kegiatan ini menggunakan media video call WhatsApp satu pertemuan satu anak dan setiap anak diberi waktu delapan menit. Adapun pembagian waktunya yaitu dua menit untuk pembukaan, lima menit kegiatan inti dan satu menit untuk penutup. Dalam pelaksanaanyaguru menginformasikan jadwal pelaksanaan kemudian memanggil anak dalam video call WhatsApp. Setelah terhubung guru membuka kegiatan dengan menanyakan kabar anak danberdo'a bersama. Setelah selesai pembukaan, guru memulai kegiatan inti dengan memberikan materi sesuai tema seperti tema diriku subtema kebutuhanku dengan materi seperti mencuci piring sendiri atau menyisir sendiri. Setelah kegiatan inti selesai kemudian guru menutup kegiatan dengan memberikan motivasi dan berdoa bersama. 
Kegiatan ketiga yaitu mengenalkan Bahasa Minang dan Bahasa Inggris. Dalam mengenalkan bahasa selama pandemi COVID-19 guru membuat video edukatif Bahasa Minang dan Bahasa Inggris untuk satu minggu satu kali. Awal videoguru membuka dengan menjelaskan tema yang akan dipelajari. Setelah pembukaan masuk kebagian inti yaitu mengenalkan kosakata bahasayang terdiri dari tiga sampai lima kosakata bahasadan di bagian penutup guru menginstruksikan anak untuk memahami dan menghafalnya. Pada pelaksanaan pembelajaran berbasis program inovasi unggulan ini membutuhkan media yang dapat membantu dalam proses pembelajaran sehingga efektif, media yang digunakan harus sesuai dengan tema sehingga memenuhi kebutuhan proses penyajian materi. Keefektifan proses pembelajaran terjalin apabila terdapat komunikasi antara media penyalur pesan denganpenerima pesan. Komunikasi inilah didukung oleh penggunaan media dalam pembelajaran yang dapat menyampaikan tujuan sehingga tercapainya area of experience (Safitri et al., 2020). Media dapat digunakan untuk menyalurkanpesan dari pengirim ke penerima sehingga dapat merangsang perasaan, pikiran, perhatian dan minat serta perhatian siswa sedemikian rupa sehingga proses belajar terjadi (Liyana \& Kurniawan, 2019). Media juga sebagai sarana dalam menyampaikan pesan dari pendidik kepada peserta didik (Handayani, 2020). Hal ini dapat diartikan bahwa media sebagai bentuk sarana yang memberikan pesan dari pendidik ke peserta didik sehingga dapat merangsang asfek perkembangan anak. Bervariatifnya jenis mediamulai dari visual seperti buku, leaflet dan bisa juga dengan kegiatan pertemuan yang mengundang audio visual untuk memberikan informasi mengenai kegiatan anak sehingga semakin menarik (Putri et al., 2020).

\section{Evaluasi Pembelajaran Bagi Anak di TK Pembina Pasa-Balai}

Evaluasi pembelajaran pada anak usia dini di TK Pembina Pasa-Balai dilaksanakan sebagaimana evaluasi pembelajaran yang juga dilakukan secara komprehensif, seperti dengan menggunakan rubrik, melakukan analisis data dan melakukan rekapitulasi terhadap hasil belajar anak untuk dijadikan sebagai laporan semester. Ada beberapa poin penting yang diperhatikan dalam

Dalam evaluasi pembelajaran program inovasi unggulan di TK Pembina Pasa-Balai guru memberikan masukan atau pujian terhadap hasil karya anak, penilaian pembelajaran dan melaksanakan kegiatan discution and trainer (D and T).Masukan dan pujian disampaikan lewat pesan chatWwhatsApp secara personal kepada orantua setelah mengirimkan hasil karya anak yang tujuannya agar anak lebih semangat untuk belajar dan atau lebih diperbaiki apa yang masih belum berkembang. Pujian yang diberikan bertujuan untuk memotivasi anak agar lebih bersemangat lagi dalam menyimak alur-alur cerita berikutnya dan saling berlomba untuk menyajikan potongan cerita. Hindari kritikan yang menyinggung perasaan anak. Evaluasi pembelajaran sebagaiserangkaian kegiatan tentang proses dan hasil belajar peserta didik untuk menganalisis, memperoleh, dan menafsirkan data yang dilakukan secara sistematis dan berkesinambungan (Hani, 2019).

Penilaian pembelajaran di TK Pembina Pasa-Balai dilakukan dengan pemberian laporan bulanan dan semester. Penilaian sebagai proses pengukuran terhadap hasil dari kegiatan belajar anak (Wiedarti, P, 2015). Penilaian laporanbulanan dilakukan setiap satu atau dua bulansekali yang berisi nama anak, nama bulan, lingkup perkembangan, kompetensi dan indikator dan nama kegiatan. Adapun penilaian semester dilaksanakan setiap satu semester sekaliyang dikompilasikan dari nilai bulanan. Penilaiansemester berisi nama anak, nama bulan, program pengembangan, kompetensi dan indikator, hasil penilaian bulanan dan simpulan umum. Discution and trainer (D\&T) adalah kegiatan evaluasi guru di TK Pembina Pasa-Balai yang di pimpin oleh kepala sekolah setiap minggu yang kegiatannya mengevaluasi program inovasi unggulan sekolah, mengevaluasi pembelajaran mengetahui capaian perkembangan anak, mendiskusikan masalah apayang sedang terjadi dan berlatih dalam meningkatkan skill guru. Setiap permasalan yang dihadapi guru dalam semua program akan didiskusikan baik dalam masalah media pembelajaran, model pembelajaran,permasalahan anak dan lainnya. Pada kegiatan D\&T ini semua guru berlatih apa yang akan dipelajari oleh anak seperti berlatih bercerita, berlatih bahasa jawa dan inggri dan berlatih lagu-lagu anak.

\section{KESIMPULAN}

Mengatur program pembelajaran yang baik dalam konteks manajemen pembelajaran berbasisprogram inovasi unggulan merupakan salah satu upaya mempertahankan kualitas pembelajaran di masa pandemi Covid 19. Komponen yang disusun yaitu perencanaan, pelaksanaan dan evaluasi. Perencanaan pembelajaran terdiri pembuatan kurikulum, program semester, RPPM, narasi pembelajaran, pembagian bahan ajar dan pembuatan video edukasi. Pelaksanaan pembelajaran terdiri dari guru menerapkan program unggulan sekolah yaitu program panggung edukasi, platform digital learning yaitu video call WhatsApp edukasi dan bahasa edukasi yaitu Bahasa Inggris dan Bahasa Minang. Evaluasi pembelajaran terdiri dari guru memberikan pujian atau masukan terhadap anak, penilaian per tema, penilaian semester dan discution and trainer.

\section{UCAPAN TERIMA KASIH}

Terimakasih atas bimbingan dan arahan yang diberikan oleh Bapak/ibu dosen di Prodi S3 IImu Pendidikan Universitas Negeri Padang yakni ibu Rifma dan Bapak Syahril sehingga artikel ini dapat diselesaikan sebagaimana mestinya. 


\section{DAFTAR PUSTAKA}

Azwardi. (2015). Manajemen pembelajaran paud. Manajer Pendidikan, 9, 108-114.

Fitri, A. R. (2020). Early Children Education Management in Integrated Kindergarten of Mutiara Bunda Learning Management to Develop the Potential of Early Childhood. 449(Icece 2019), 125-128. https://doi.org/10.2991/assehr.k.200715.025

Fitriani, D., Fajriah, H., \& Rahmita, W. (2019). Media Belajar Big Book dalam Mengembangkan Kemampuan Berbahasa Reseptif Anak Usia Dini. Jurnal Obsesi : Jurnal Pendidikan Anak Usia Dini, 4(1), 247. https://doi.org/10.31004/obsesi.v4i1.197

Gusliati, P., Eliza, D., \& Hartati, S. (2019). Analisis Video Pembelajaran Share Book Reading Menggunakan Cerita Rakyat Sabai Nan Aluih pada Anak Usia Dini. Jurnal Obsesi : Jurnal Pendidikan Anak Usia Dini, 3(2), 320. https://doi.org/10.31004/obsesi.v3i2.176

Hadiati, E., \& Fidrayani, F. (2019). Manajemen Pembelajaran Pendidikan Anak Usia Dini. Al-Athfaal: Jurnal Ilmiah Pendidikan Anak Usia Dini, 2(1), 69-78. https://doi.org/10.24042/ajipaud.v2i1.4818

Handayani, O. D. (2020). Pengembangan Media Pembelajaran PAUD melalui PPG. Jurnal Obsesi : Jurnal Pendidikan Anak Usia Dini, 5(1), 93. https://doi.org/10.31004/obsesi.v5i1.522

Hani, A. A. (2019). Evaluasi Pembelajaran pada PAUD. Care, 7(1), 52-56.

Hanifah, H. (2018). Penerapan Manajemen Program Pembelajaran Bagi Guru Paud Dalam Meningkatkan Kinerja Pendidik. Comm-Edu (Community Education Journal), 1(3), 24. https://doi.org/10.22460/commedu.v1i3.1102

Karim, A. A. (2021). Jurnal Smart Paud. 4(1), 1-10.

Kemendikbud. (2020). Penilaian Pembelajaran Pendidikan Anak Usia Dini. Ditjen PAUD dan Pendidikan Masyarakat Direktorat Pembinaan PAUD.

Liyana, A., \& Kurniawan, M. (2019). Speaking Pyramid sebagai Media Pembelajaran Kosa Kata Bahasa Inggris Anak Usia 5-6 Tahun. Jurnal Obsesi : Jurnal Pendidikan Anak Usia Dini, 3(1), 225. https://doi.org/10.31004/obsesi.v3i1.178

Nurmiati. (2018). Penyusunan Kurikulum Tingkat Satuan Pendidikan PAUD. Kementerian Pendidikan dan Kebudayaan Dirjen PAUD dan Pendidikan Masyarakat Direktorat Pembinaan PAUD.

Putri, D. K., Handayani, M., \& Akbar, Z. (2020). Pengaruh Media Pembelajaran dan Motivasi Diri terhadap Keterlibatan Orang Tua dalam Pendidikan Anak. Jurnal Obsesi : Jurnal Pendidikan Anak Usia Dini, 4(2), 649. https://doi.org/10.31004/obsesi.v4i2.418

Safitri, A., Kabiba, K., Nasir, N., \& Nurlina, N. (2020). Manajemen Pembelajaran bagi Anak Usia Dini dalam Meningkatkan Kualitas Pembelajaran. Jurnal Obsesi : Jurnal Pendidikan Anak Usia Dini, 5(2), 1209-1220. https://doi.org/10.31004/obsesi.v5i2.811

Sriwahyuni, E., Asvio, N., \& Nofialdi, N. (2017). Metode Pembelajaran Yang Digunakan Paud (Pendidikan Anak Usia Dini) Permata Bunda. ThufuLA: Jurnal Inovasi Pendidikan Guru Raudhatul Athfal, 4(1), 44. https://doi.org/10.21043/thufula.v4i1.2010

Suyadi. (2011). Manajemen PAUD. Pustaka Pelajar.

Syah, R. H. (2020). Dampak Covid-19 pada Pendidikan di Indonesia: Sekolah, Keterampilan, dan Proses Pembelajaran. SALAM: Jurnal Sosial Dan Budaya Syar-I, 7(5). https://doi.org/10.15408/sjsbs.v7i5.15314

Utiarahman, A., Djafri, N., \& Badu, S. Q. (2020). Manajemen Tehnik Pembelajaran Pendidikan Anak Usia Dini di Kawasan Pesisir Laut Kabupaten Gorontalo Utara. Jurnal Obsesi : Jurnal Pendidikan Anak Usia Dini, 4(2), 932. https://doi.org/10.31004/obsesi.v4i2.497

Wahyuni, M. (2021). Video Tutorials on Education Statistics Course Assisted with Screencastify : Validity and Feasibility. $5,86-93$.

Wiedarti, P, et. a. (2015). Desain Induk Gerakan Literasi. Kemendikbud. 